\title{
An Interesting Unusual Case of Hypokalemic Quadriparesis in 48 Years Hypertensive Male Patient: A Liddle's Syndrome
}

\author{
${ }^{1}$ Manoj Kumar Roy, ${ }^{2}$ Apratim Chatterjee, ${ }^{3}$ Anup Sarkar, ${ }^{4}$ Koushik Roy, ${ }^{5}$ Durjoy Lahiri, ${ }^{6}$ Rakesh Agarwal \\ ${ }^{7}$ Sumanto Mukhopadhyay, ${ }^{8}$ Jotideb Mukhopadhyay
}

\begin{abstract}
In 1963, Liddle et al described a disorder that looks like the features of primary aldosteronism, characterized by severe hypertension and hypokalemia but with negligible secretion of aldosterone. They theorized that this was 'a disorder in which the renal tubles transport ions with such facility that the end result simulates that of a mineralocorticoid excess'. Liddle's syndrome involves abnormal kidney function, with excess reabsorption of sodium and loss of potassium from the renal tubule, and is treated with a combination of low sodium diet and potassiumsparing diuretic drugs (e.g. amiloride). We are reporting a case of 48 years known hypertensive patient admitted with acute onset quadriparesis, ultimately diagnosed as hypokalemia due to Liddle's syndrome, treated with low sodium salt and potassium sparing diuretics-amiloride responds dramatically.
\end{abstract}

Keyword: Amiloride, Hypertensive, Hypokalemia, Liddle's syndrome, Quadriparesis.

How to cite this article: Roy MK, Chatterjee A, Sarkar A, Roy K, Lahiri D, Agarwal R, Mukhopadhyay S, Mukhopadhyay J. An Interesting Unusual Case of Hypokalemic Quadriparesis in 48 Years Hypertensive Male Patient: A Liddle's Syndrome. J Postgrad Med Edu Res 2015;49(3):143-145.

Source of support: Nil

Conflict of interest: None

\section{INTRODUCTION}

Hypokalemia in a patient with hypertension almost always suggest a secondary cause of hypertension. There are few conditions associated with this syndrome of hypertension and hypokalemia. We describe a rare interesting case of a patient with a rare syndrome of hypertension, hypokalemia and periodic paralysis: Liddle's syndrome. Though it is an autosomal dominant disease it can present at any age with features varying from only hypertension to even hypokalemic quadriparesis. Worldwise about 30 cases have been reported which may be a tip of the iceberg.

\footnotetext{
${ }^{1-7}$ Resident, ${ }^{8}$ Professor and Head

${ }^{1-8}$ Internal Medicine, Institute of Post Graduate Medical Education and Research, Kolkata, India
}

Corresponding Author: Manoj Kumar Roy, Resident, Junior Doctor's Hostel, SSKM Hospital, IPGMER, AJC Bose Road Kolkata, India, e-mail: drmanojroy@gmail.com

\section{CASE REPORT}

A 46-year-old male patient, known hypertensive, nondiabetic presented with acute onset symmetrical flaccid quadriparesis involving all limbs at same time over a period of 3 days before admission. It was associated with myalgia. There was no history suggestive of sensory involvement, cranial nerve involvement. Bowel bladder control was preserved. There was no history of neck pain or trauma. There was no history of recent diarrhea, vomiting or respiratory tract infection. Past family history was noncontributory. The patient was known smoker and occasional alcoholic.

Examination revealed higher mental functions was normal. Pulse rate was 88 beats/minute, regular; Blood pressure was 186/110 mm Hg, Respiratory rate was $14 /$ minute. Patient was afebrile. Secondary sexual character was normal on examination. No bruit was found in carotid, renal artery. Neurological survey revealed power of both upper limbs to be $3 / 5$ and lower limbs to be $2 / 5$. Deep tendon jerks were normal in both upper and lower limbs. There was no sign of sensory loss. Sensorium was normal. Posterior column senses were preserved. No sign of cranial nerve involvement, cerebellar involvement or autonomic dysfunction was found. Other systemic examinations were inconclusive.

Investigation revealed Hemoglobin of $11.6 \mathrm{gm} / \mathrm{dl}$. Total count of $6400 / \mathrm{mm}^{3}$, with normal differential leukocyte count. Platelet-count was 2.54 lakhs $/ \mathrm{mm}^{3}$. Fasting blood sugar and postprandial sugar were: $104 \mathrm{mg} / \mathrm{dl}$, $130 \mathrm{mg} / \mathrm{dl}$ respectively. Urea: $28 \mathrm{mg} / \mathrm{dl}$, creatinine: $0.9 \mathrm{mg} / \mathrm{dl}, \mathrm{Na}^{+}-146 \mathrm{mMol} / \mathrm{l}, \mathrm{K}^{+}-1.1 \mathrm{mMol} / \mathrm{l}$. Arterial blood gas analysis showed $\mathrm{pH}$ of 7.497 suggestive of metabolic alkalosis. Thyroid function test was normal. Potassium was replaced slowly through intravenous route. The patient recovered partially and his repeat potassium was $2.3 \mathrm{mMol} / 1$ on day 2 of hospital admission. Oral potassium supplement started thereafter from day 3. His plasma osmolarity was $260.7 \mathrm{mosm} / \mathrm{kg}$ and urine osmolarity was $241.08 \mathrm{mosm} / \mathrm{kg}$. Spot urine potassium was $27.1 \mathrm{mMol} / 1$. Urinary transtubular potassium gradient (TTKG) was found to be 9.8 which was considerably high indicating that there was urinary loss of potassium. 


\section{BIOCHEMICAL PARAMETERS}

\begin{tabular}{|c|c|c|c|c|}
\hline $\begin{array}{l}\text { Day of } \\
\text { hospital } \\
\text { stay }\end{array}$ & $\begin{array}{l}\text { Serum } \mathrm{Na}^{+} \\
(\mathrm{mMol} / \mathrm{l})\end{array}$ & $\begin{array}{l}\text { Serum } K^{+} \\
(\mathrm{mMol} / \mathrm{l})\end{array}$ & Blood pH & $\begin{array}{l}\text { Blood } \\
\text { pressure } \\
\text { (mm Hg) }\end{array}$ \\
\hline Day 1 & 146.4 & 1.1 & 7.497 & $186 / 110$ \\
\hline Day 2 & 138.9 & 2.3 & 7.490 & $190 / 106$ \\
\hline Day 4 & 140.6 & 2.9 & 7.486 & $184 / 98$ \\
\hline Day 5 & 137.5 & 3.8 & 7.389 & $178 / 100$ \\
\hline
\end{tabular}

After supplementing oral potassium $60 \mathrm{mMol} /$ day for 3 days, serum potassium was measured and it was found to be $3.8 \mathrm{mMol} / 1$. The patient recovered from his weakness by that time. His plasma aldosterone was measured to be $6.7 \mathrm{ng} / \mathrm{dl}$ and plasma renin activity was $1.43 \mathrm{ng} / \mathrm{ml} / \mathrm{hr}$ in resting supine position.

\section{ENDOCRINAL PARAMETERS}

\begin{tabular}{|c|c|c|c|c|c|}
\hline $\begin{array}{l}\text { Day of } \\
\text { hospital } \\
\text { stay }\end{array}$ & $\begin{array}{l}\text { Plasma } \\
\text { renin } \\
\text { activity } \\
(\mathrm{ng} / \mathrm{ml} / \mathrm{hr})\end{array}$ & $\begin{array}{l}\text { Plasma } \\
\text { aldosterone } \\
\text { (ng/ml) }\end{array}$ & $\begin{array}{l}\text { Plasma } \\
\text { cortisol } \\
\text { ( } \mu \mathrm{g} / \mathrm{dl})\end{array}$ & $\begin{array}{l}24 \text { Hours } \\
\text { urinary } \\
\text { free } \\
\text { cortisol } \\
\text { ( } \mu g / \text { day) }\end{array}$ & $\begin{array}{l}\text { Plasma } \\
\text { ACTH } \\
\text { pg/ml) }\end{array}$ \\
\hline Day 3 & $\begin{array}{l}1.43 \\
\text { (Resting: } \\
0.15-2.33 \text { ) }\end{array}$ & $\begin{array}{l}6.7 \\
\text { (Resting: } \\
1.0-16.0)\end{array}$ & & & \\
\hline Day 5 & & & $\begin{array}{l}8 \text { a.m: } \\
14.67 \\
(5-18) \\
4 \text { p.m: } \\
11.8 \\
(2-13)\end{array}$ & $\begin{array}{l}25.7 \\
(20-90)\end{array}$ & $\begin{array}{l}23.7 \\
(6-56.7)\end{array}$ \\
\hline Day 7 & $\begin{array}{l}1.48 \\
\text { (Resting: } \\
0.15-2.33 \text { ) }\end{array}$ & $\begin{array}{l}5.8 \\
\text { (Resting: } \\
\text { 1.0-16.0) }\end{array}$ & & & \\
\hline
\end{tabular}

Values in parenthesis indicate normal range

Ultrasonography of abdomen and contrast-enhanced computer tomography of abdomen was absolutely normal without any adrenal mass lesion. Renal arterial Doppler study revealed no renal artery stenosis. Electromyogram/Nerve Conduction Study (EMG-NCS) study was normal. Magnetic resonance imaging cervical spine was done which revealed degenerative changes without any spinal canal stenosis. Patient was given a trial of spironolactone but blood pressure was persistently on higher range. Then, we started a trial of amiloride $5 \mathrm{mg}$ twice daily for 3 days. Blood pressure normalized after 3 days along with serum potassium level. On follow-up after 2 weeks of medication, without any oral potassium supplement, his serum potassium was found to be $4.05 \mathrm{mMol} / 1$. His BP was $132 / 80$ on followup visit.

\section{DISCUSSION}

Liddle's syndrome is an autosomal dominant form of saltsensitive hypertension characterized by increased plasma volume caused by excessive salt and water reabsorption in the distal nephron, resulting in low levels of plasma renin activity and aldosterone, and increased potassium excretion, resulting in low levels of serum potassium and metabolic alkalosis. ${ }^{1-3}$ Mostly present at a young age though occasionally cases may not be detected until well into adulthood. However, presentation in the 6th decade of life or later has been reported very rarely. ${ }^{3-5}$ However, these patients have low renin and aldosterone levels and there is conservation of sodium and excretion of potassium in the absence of mineralocorticoid excess. Genetic studies have revealed that mutations affecting cytosolic tail of the $\beta$ subunit of the epithelial sodium channel $(\mathrm{ENaC})$ could lead to this disorder. ${ }^{6-8}$ These mutations apparently cause constitutive activation of the epithelial sodium channel of the luminal membrane of the collecting tubule and result in excessive absorption of sodium leading to volume expansion. ${ }^{9}$ This in turn causes hypertension, leading to inhibition of renin and aldosterone secretion. A lack of down-regulation of the epithelial sodium channels despite persistent volume expansion is the basis behind the pathogenesis of this syndrome. ${ }^{2}$

It is important to screen for this condition in patients with hypertension, hypokalemia and metabolic alkalosis, as the treatment of Liddle's syndrome differs from other forms of essential or secondary hypertension..$^{10}$ Potassiumsparing diuretics, like amiloride and triamterene which directly close the sodium channels are effective in Liddle's syndrome, whereas mineralocorticoid antagonist spironolactone is ineffective since the increase in sodium channel activity is not mediated by aldosterone in this disorder. ${ }^{10}$

Patient with hypertension and hypokalemia in response to amiloride provided additional evidence that patient may be suffering from Liddle's syndrome, whereas spironolactone fails to control hypertension and hypokalemia.

Differential diagnosis of secondary hypertension in this case was renal artery stenosis, Cushing's syndrome, Conn's syndrome (aldosterone secreting adenoma or bilateral adrenal hyperplasia) and hyperthyroidism. All these causes were excluded sequentially by normal renal artery Doppler, computer tomography, plasma aldosterone and plasma renin activity, thyroid function test, fasting cortisol, 24 hours urinary free cortisol. There are two enzymes $11-\beta$ hydroxylase and $5-\beta$ reductase which is associated with 'syndrome of apparent mineralocorticoid excess (SAME)', in which deficiency of those enzymes cause inability to convert cortisol into its inactive metabolite cortisone. ${ }^{11}$ Eleven hydroxy cortisol metabolites act on mineralocorticoid receptor in renal tubule resulting in sodium retention and potassium excretion with hypertension which usually responds to spironolactone. 
Glycyrrhizic acid, an active component of licorice, produces manifestation similar to the apparent mineralocorticoid excess by suppression of $11-\beta$ hydroxysteroid dehydrogenase. As the patient has absence of virilization or hypogonadism, no response to spironolactone with very good response to amiloride could exclude the syndrome of apparent mineralocorticoid excess.

In the diagnosis of weakness in a background of hypertension, Liddle's syndrome should be considered in adult and elderly patient. In young patient are suspected to have Liddle's syndrome based on the presence of hypertension alone, whereas diagnosis of the disease in the majority of elderly patients were based on muscle weakness rather than hypertension in the clinical observation. ${ }^{5}$

Liddle's syndrome is autosomal dominant disorder which may occur in the family member. ${ }^{12}$ Patient has one son and one daughter both of them were normotensive. So, our aim of the case report is that all treating physician should suspect any patient with features of hypokalemia in a background history of hypertension after excluding other secondary causes of hypertension as Liddle's syndrome which can present even at older age, diagnosis of which is very important in treating this type of patient and prevent further deterioration by diuretics other than amiloride or triamterene.

\section{REFERENCES}

1. Liddle GQ, Bledsoe T, Coppage WS Jr. A familial renal disorder simulating primary aldosteronism but with negligible aldosterone secretion. Trans Assoc Am Physicians 1963;76: 199-213.
2. Scheinman SJ, Guay-Woodford LM, Thakker RV, WarnockDG. Genetic disorder of renal electrolyte transport. N Engl J Med 1999;340(15):1177.

3. Botero-Velez M, Curtis JJ, Warnock DG. Brief report: Liddle's syndrome revisited. N Engl J Med 1994;330(3):178-181.

4. Oh J, Kwon KH. Liddle's syndrome: a report in a middle-aged woman. Yonsei Med J 2000;41(2):276-280.

5. Tetsuro M, Yoshiyuki M, Kazuaki Y, Katsuyuki F, et al. Liddle's syndrome in an elderly woman. Intern Med 1998;37(4): 391-395.

6. Rose BD. Genetic disorders of the renal sodium channel: Liddle's syndrome and type 1 pseudohypoaldosteronism. [Online]. 2007 May 10 [cited 2007 December 23]; Available at: URL: http://www.utdol.com.

7. Shimkets RA, Warnock DG, Bositis CM, et al. Liddle's syndrome: heritable human hypertension caused by mutations in the $\mathrm{b}$ subunit of the epithelial sodium channel. Cell 1994;79(3):407-414.

8. Hansson JH, Schild L, Lu Y, et al. A de novo missense mutation of the beta subunit of the epithelial sodium channel causes hypertension and Liddle's syndrome and identifies a prolinerich segment of the protein critical for regulation of channel activity. Proc Natl Acad Sci USA 1995;92(25):11495-11499.

9. Snyder PM, Price MP, McDonald FJ, et al. Mechanism by which Liddle's syndrome mutations increase activity of human epithelia Na1 channel. Cell 1995;83(6):969-978.

10. Rezkalla L, Borra S. Saline-resistant metabolic alkalosis, severe hypokalemia and hypertension in a 74-year-old woman. Clin Nephrol 2000;53(1):66-70.

11. Stewart PM, Corrie JET, Shackleton CHL, Edwards CRW Syndrome of apparent mineralocorticoid excess: a defect in the Cortisol-cortisone shuttle. J Clin Invest 1988;82(1): 340-349.

12. XavierJ,Frederic B, AlexandreP, Cecile D, Guy C, Michel L, et al. Genotype-phenotype analysis of a newly discovered family with Liddle's syndrome. J Hypertens 1997;15(10):1091-1100. 